\title{
Governor Pio Pico, the monster of California...no more: lessons in neuroendocrinology
}

\author{
Ivan S. Login · Jessica Login
}

Published online: 3 July 2008

(c) The Author(s) 2008

\begin{abstract}
We hypothesize that Pio Pico, the last Mexican Governor of California, had acromegaly between at least ages 43 to 57, from 1844 to 1858 , before Pierre Marie published the clinical description of acromegaly in 1886 . Pico's probable growth hormone-secreting pituitary tumor likely infarcted spontaneously after 1858. The tumor infarction resulted in burnt-out acromegaly and probably restored normal pituitary function. Pearce Bailey published the first account of pituitary tumor infarction only in 1898 . Pico's undiagnosed, misunderstood, profoundly acromegalic appearance was widely misinterpreted, leading to pervasive, degrading, and highly prejudicial comments. This landmark case study in neuroendocrinology provides the opportunity to re-examine elements of 19 th century California and American history.
\end{abstract}

Keywords Pio Pico - Neuroendocrinology .

Pituitary tumor · Acromegaly $\cdot$ Pituitary tumor apoplexy

A souvenir San Diego postcard of Pio Pico mailed by one author (JL), to commemorate Pico's role as the last Mexican Governor of California (Fig. 1), prompted this investigation. His image evokes the appearance of

The authors report no conflicts of interest.

I. S. Login ( $\square)$

Department of Neurology, University of Virginia School of

Medicine, Box 800394, Charlottesville, VA 22908, USA

e-mail: isl@hscmail.mcc.virginia.edu

J. Login

Washington Elementary School, 825 Taylor Avenue, Alameda, CA 95401, USA acromegaly. We could not identify any reference to this aspect of his life.

Pio Pico's appearance reveals signs commonly indicating excess growth hormone (GH) secretion [1]. He has coarse facial features, a broad forehead, wide bulbous nose, thick protuberant lips, and a forward jutting jaw (Fig. 1). His fingers and hand breadth are massive. Of his parents and nine living siblings, only his younger brother, Andres Pico, is frequently imaged (Fig. 2) and he appears normal.

Pio de Jesus Pico IV was born May 5, 1801. An 1847 oil painting (Fig. 3) shows acromegalic features similar to Fig. 1. Even at age 43 "Don Pio was heavy and coarse in appearance...perhaps from self-indulgence...elephantiasis or gland trouble" [2, p. 266]. His normal height of about $5 \mathrm{ft} 7$ in. in July 1848 suggests acromegaly began after puberty [3, p. 157].

Unregulated GH release most commonly arises from an anterior pituitary GH-secreting adenoma. Pio Pico exhibits three manifestations of his tumor. First, he persuasively demonstrates the systemic effects of GH excess (Fig. 1). Second, he has dysconjugate gaze (Fig. 1, inset). With a presumed pituitary adenoma this sign implies lateral growth from the sella turcica into the adjacent cavernous sinus. In 1858 he appears more acromegalic, but now with striking left eye displacement and slight proptosis (Fig. 4). Third, he has apparent secondary thyrotropin deficiency manifesting as the loss of lateral eyebrows [4] and, at least by history (see below), possible secondary hypogonadism, each of which can result from mass effect of his presumed GH-secreting tumor on the adjacent normal pituitary (Fig. 4). Up to $30 \%$ of GH-secreting pituitary tumors also produce excess prolactin [5] which can independently inhibit gonadotropin function.

Pio Pico married Maria Ignacia Alvarado on February 24, 1834 and she died in 1854 [6, p. 61]. In 1877 Pio 


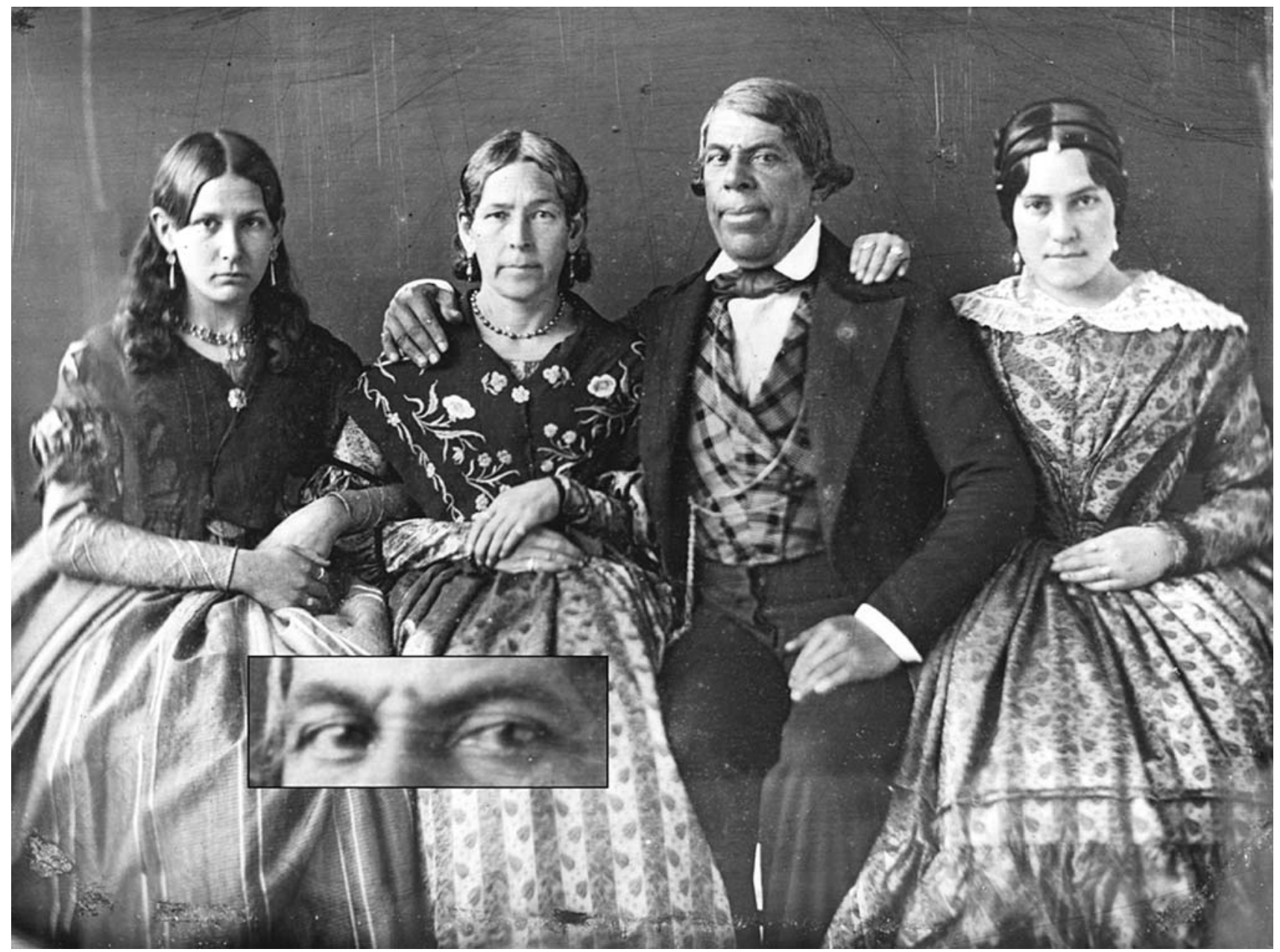

Fig. 1 A daguerreotype c. 1852 shows Pio Pico at age 51. He drapes his arm around his wife with two nieces flanking the couple. This is his earliest objective published image and demonstrates signs of

dictated 200 pages of his memoirs in Spanish (he spoke no English) to Thomas Savage who was collating recollections of "Californios" for the Bancroft historical collection in California. This was translated and published in English in 1973 [7]. Pio traced his life from 1801 to 1877 and never acknowledged any children born to him and Maria or to any other woman. However, the forward of this narrative memoir stated he died September 11, 1894, at 93, in the home of his daughter, Joaquina Pico Moreno [7, p. 15]. This apparent paradox raises a question regarding his fertility.

Pio and Maria apparently had no biological children [6, p. 61,8, p. 779,9 , p. 15$]$. It was atypical however, to have no children in that era, suggesting infertility. His father, Jose Maria Pico, had four siblings; one of whom, Jose Dolores Pico, had thirteen children [7, p. 19]. Pio's mother had six half-siblings [7, p. 20]. Pio's parents had 12 children, with two dying in infancy [6, p. 33]. One of Pio's sisters had three sons [6, p. 44]. Thus, a childless marriage apparent acromegaly. The enlarged inset emphasizes his dysconjugate gaze but with normal lateral eyebrows. Courtesy of the Los Angeles County Museum of Natural History Foundation

like Pio and Maria's was also uncommon in this family and suggests infertility. Was Pio the infertile partner? His smooth face without beard or mustache (Fig. 1, 3, 4) could support that contention based on secondary hypogonadism.

Griselda and Joaquina Avila and Ranulfo and Alfredo Romero all claimed to be descendants of Pio Pico. However, major debate continues over their status as biological [6, p. 62, 10] or adopted children [9, p. 15, 11, 12]. Ascencion Avila bore Griselda in 1838 and later, Joaquina, at whose home Pio died. Felicita Romero gave birth to brothers, Ranulfo in 1862 and Alfredo in 1871. Griselda, Joaquina, and Alfredo were ruled the biological children of Pio Pico by a Los Angeles court in an estate matter after Pio died [6, pp. 61-62], but the ruling is simply a legal opinion without biological significance. The facts about these descendants are controversial. We hypothesize the absence of children with Maria after their marriage in 1834 resulted from Pio's infertility and therefore he was unlikely to be the father of Grisella and Joaquina. If Pio's secondary 


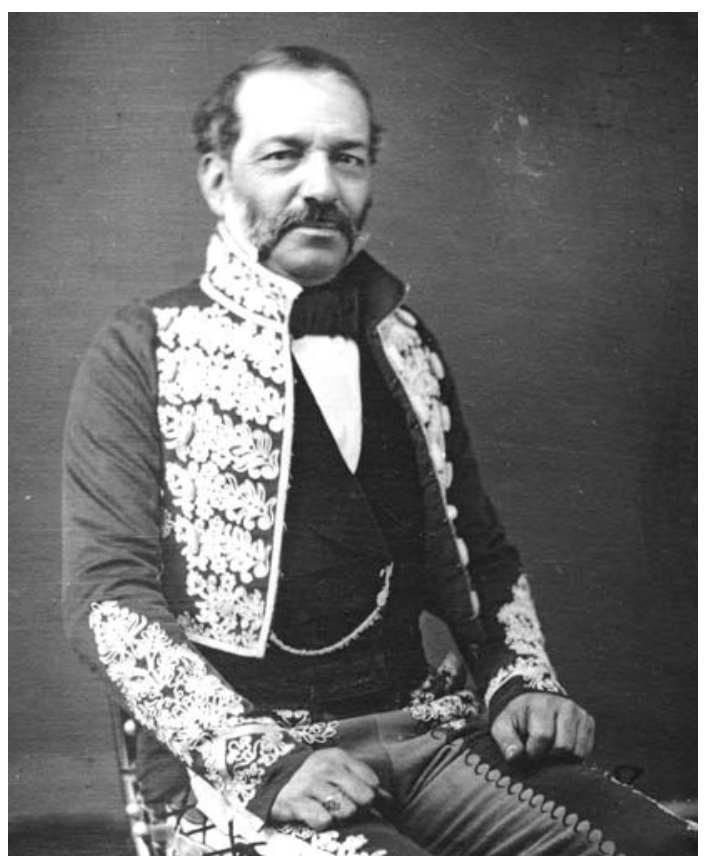

Fig. 2 This undated image shows Pio's younger brother Andres Pico (1810-1876). Andres had fine facial features, slender fingers, and hands with a ring on the right, and closely manicured facial hair. This healthy appearance minimizes the probability that the Pico family had an acromegaloid look in general, potentially a more trivial explanation for the striking qualities in Pio Pico. Courtesy of the Los Angeles County Museum of Natural History Foundation

hypogonadism manifested only after 1838 when Grisella and Joaquina were born, Pio could have fathered these two girls but still not had children earlier in his own marriage, suggesting perhaps Maria was the infertile partner. However, we surmise the collective observations about his presumed tumor support the probability that Pio was the infertile partner. The genealogy of the two Romero boys may require a different analysis, as described below.

Critical discrepancies also swirl about the concept of "wife" in the historical record. Some state he never married after Maria died [9, p. 16, 12, 13]. Others claim that following her death, a housekeeper became his mistress [3, p. 201] or common law wife, and bore him children [14]. An undated image labeled "Don Pio Pico and his wife" [15] shows Pio sitting beside an unidentified woman who is not Maria. Thus, if he did actually father children, when did this occur, with which "wife," and what was the contemporaneous status of his acromegaly?

Pio Pico was not recognized to have acromegaly because the concept was advanced only in 1886,14 years after his daguerrotype in Fig. 1, and half a world away in France by Pierre Marie [16], chief of clinic under Charcot [17]. The original French publication was largely abstracted into English in 1891 [18]. Marie described two women seen personally, Fusch and Heron, with an unusual noncongenital hypertrophy of the head and upper and lower extremities [18]. In Case I, “...when [Fusch] came to Professor Charcot's out-patient department, though she complained of a violent neuralgia in the head, it was [the enlarged hands] that first attracted attention. The entire hand had undergone an increase in size...which...if they belonged to a giant their appearance would present nothing abnormal..." He presented in text and woodcut images a particular alteration of the head with, "...hypertrophy of the nose, malar bones, and lower jaw..." Along with five additional examples of the same apparent undiagnosed condition that he culled from the literature, Marie coined a term describing the distinct clinical entity, Acromegalie. $\mathrm{He}$ noted a case by Saucerotte published in 1801 [19], perhaps the earliest published example of acromegaly. Marie did not identify an etiology for Acromegalie.

In recognition of Marie's critical insight, his colleague, J.D. de Souza-Leite, re-presented Marie's two personal cases along with others under the heading, "Marie's Malady," noting "To Dr. P. Marie is due the merit of recognizing [acromegaly] as a distinct malady, and of describing it in such a manner that it can be identified by everyone" [18]. By 1891 there were at least seven autopsied cases and, "the most specific [lesion] is the considerable increase in size of the pituitary body...from a pigeon's egg...to a hen's egg, or even an apple" [18]. By this time, Heron had died and Souza-Leite displayed her brain and skull base revealing the enormous pituitary gland and correspondingly massive sella turcica. The pituitary tissue, however, was considered hypertrophied, not neoplastic, and simply another manifestation of the same inexplicable process that enlarged so many other parts of the body. The essential pituitary role in acromegaly has since been illuminated $[5,17,20,21]$.

The 1852 daguerrotype may be the earliest objective representation of acromegaly not otherwise influenced by subjective artistic rendition in paint, woodcut or sculpture [17]. In contrast, pre-pubertal GH excess with gigantism was more commonly recognized and true giants were often featured in European circuses from the 1600s. P.T. Barnum actually married a Quaker Giant and Giantess to each other on his stage on February 17, 1849 [22].

We propose that later, Pio Pico's unrecognized pituitary tumor spontaneously and selectively infarcted, acromegaly disappeared and normal pituitary function resumed. Acromegaly, a chronic debilitating illness, more than doubles the mortality risk without adequate treatment; $80 \%$ succumb within 10 years of diagnosis [5]. It would be highly unlikely that a man with untreated acromegaly would survive almost 50 years to age 93 .

He did not appear acromegalic in his 80s (Fig. 5A). His coarse facial features had improved considerably. His fingers were slender, with a ring on the right hand. His normal appearing left hand held his "trademark" cane with an 
Fig. 3 This is a $15 \times 24$ in. full-length oil-on-paper portrait of Pio Pico c. 1847 donated in 1912 by Mrs. George A. Johnson, Pico's niece and the former Estefana Alvarado.

Many of Mr. Pico's acromegalic features are apparent at age 46. Considering artistic rendition, the light reflections are symmetrical on each eye. Courtesy of the California History Section, California State Library, Sacramento, California

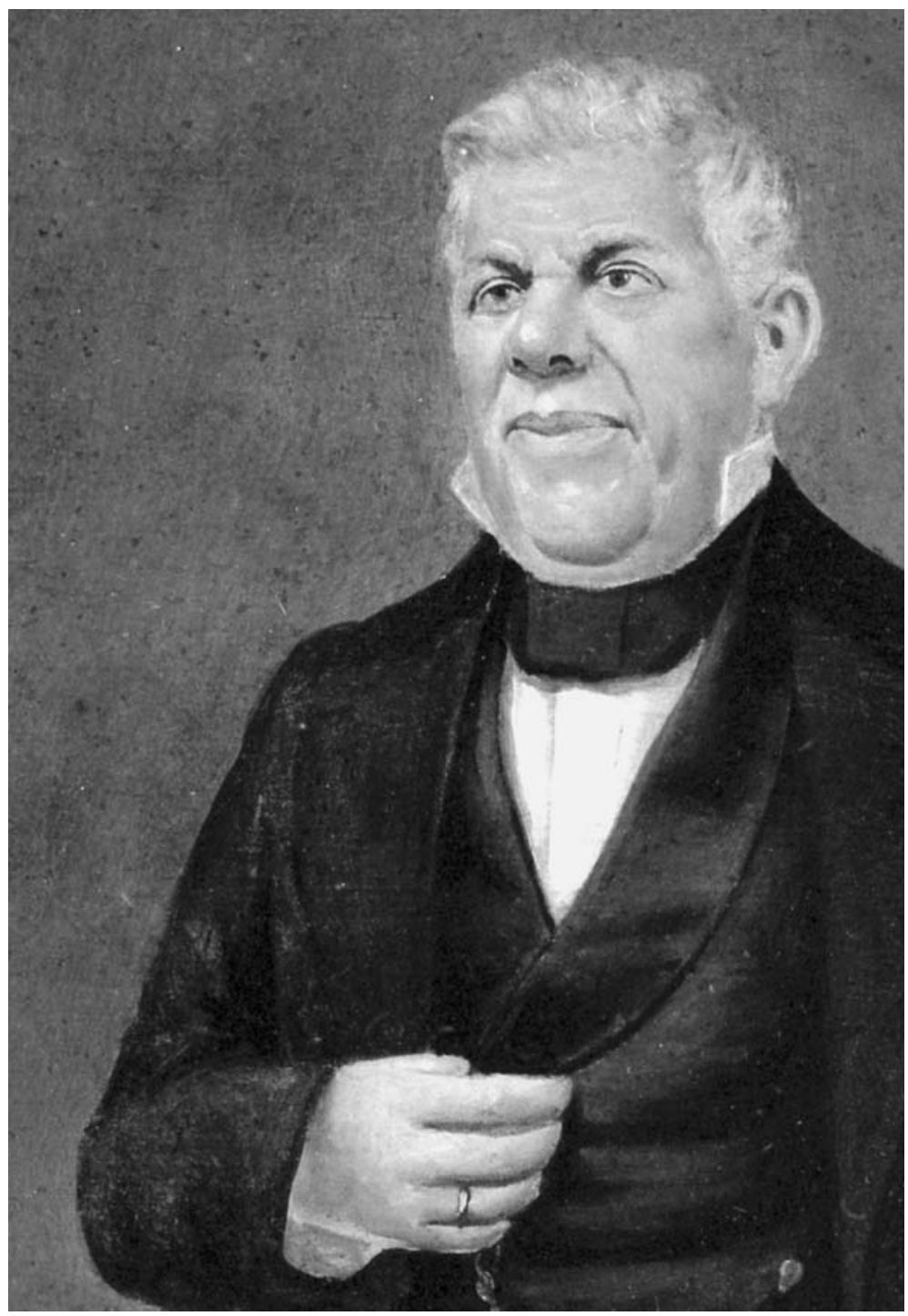

ivory female leg protruding upward, bent at the knee like a can-can dancer [6, p. 164]. His robust bushy beard contrasted sharply with his earlier images to suggest restoration of gonadotropin function. His gaze became conjugate (Fig. 5B) supporting the proposal that the earlier dysconjugate gaze and proptosis resulted from an invasive tumor. Additionally, Mr. Pico's lateral eyebrows became evident (see also [23]).

Finally, sometime after 1858 when his endocrinopathy resolved he may have conceived children with another "wife" [14, 15], or with others (such as Felicita Romero), leading to children born in or after 1862. Alfredo Romero Pico (born 1871) was said to look exactly like Pio Pico [12].

This apparent tumor infarction abolished the clinical manifestations of acromegaly and the tumor mass effect to generate healthy gonadotropin and thyrotropin function, and cavernous sinus anatomy. The rare patient recovers from pituitary tumor infarction without need for endocrine replacement therapy [24]. This clinical event could occur asymptomatically, or explosively as pituitary tumor apoplexy [24]. In the only medical reference we discovered, he was "bedridden... unable to ride a horse...gravely ill...half dead" for several weeks followed by full recovery [7, pp. 77-85]. This account could suggest pituitary tumor apoplexy but it occurred early in 1839. Because his acromegalic features (Fig. 1, 4) were obvious 10 to 20 years after this illness, we judge this was not an episode of pituitary tumor infarction. The metabolic and soft tissue manifestations of acromegaly typically start to improve within hours of tumor removal [25]. We have not located any other medical history highlighting the timing of his tumor infarction.

The first publication of spontaneous pituitary tumor infarction was only in 1898 in a man who may have had acromegaly [24, 26]. The photographic and historical 


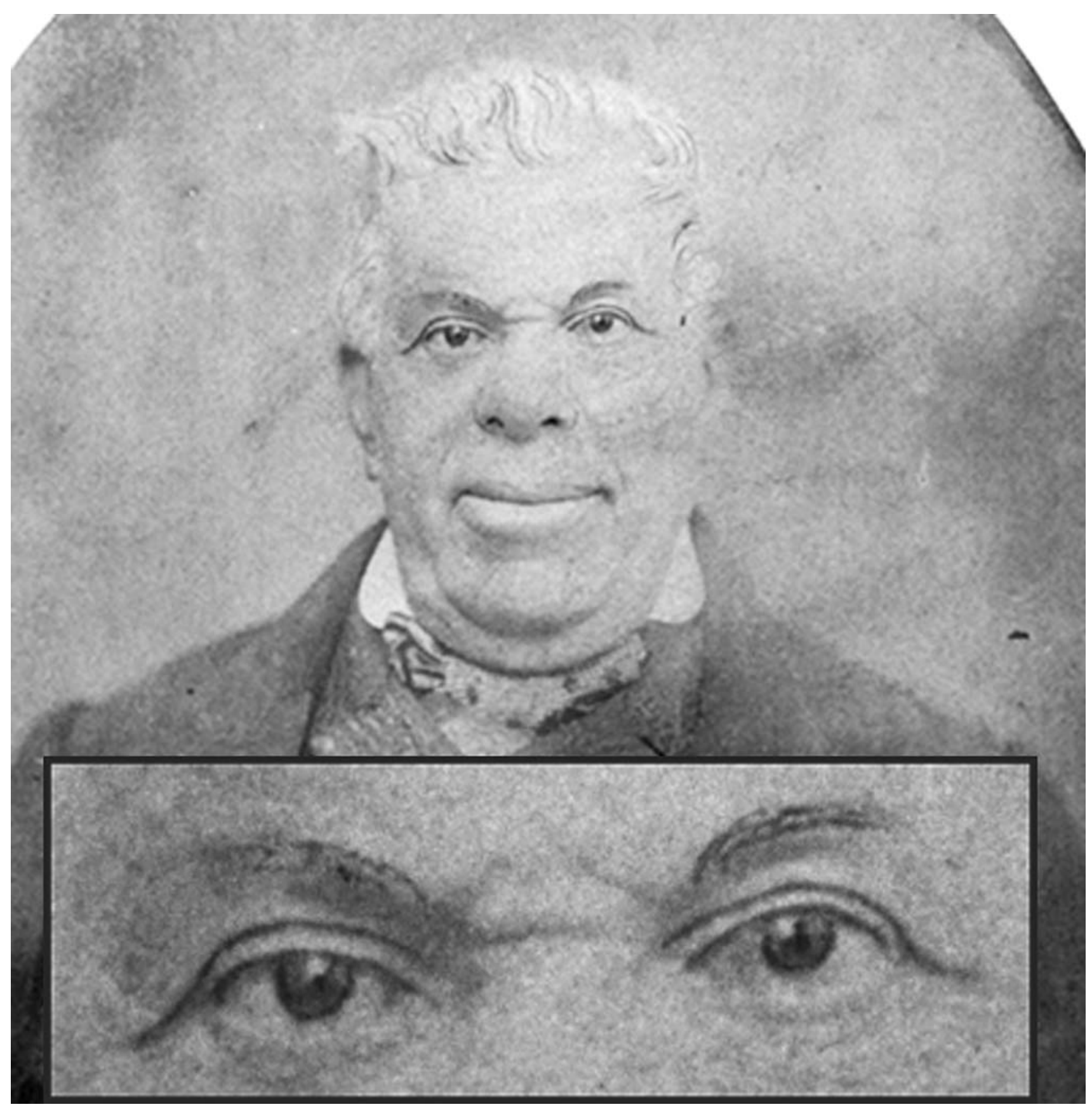

Fig. 4 Pio Pico has striking clinical features of acromegaly in 1858 about 4 years after the death of his wife, Maria Ignacia. The left ocular globe is mildly proptotic and located eccentrically in the orbit compatible with tumor extension into the left cavernous sinus and orbit. Note the marked asymmetry of the location of the light reflection in each eye. We are unable to assess pupillary size. His

records of Pio Pico's life suggest that his course and experience antedated Bailey's account perhaps by decades.

Because he was ridiculed and castigated for his appearance, the medical history of Pio Pico has potential societal ramifications beyond these neuroendocrine abnormalities. Pio had African, Indian and European ancestry; hairless face could reflect secondary hypogonadism. The enlarged inset emphasizes his dysconjugate gaze and the loss of lateral eyebrows (compare with Fig. 1) suggesting hypothyroidism. At this point in his life he was a successful rancher, businessman, and landowner. Courtesy of the Bancroft Library, University of California at Berkeley

his social status was relatively low in a highly racist society with over 16 different caste categories [3, p. 24]. He dealt with prejudice and racism much of his life [personal communication, Perez B, 3, 27]. For example, "a prominent San Francisco attorney, sharing the prejudices of the American establishment and local feeling in San Francisco 


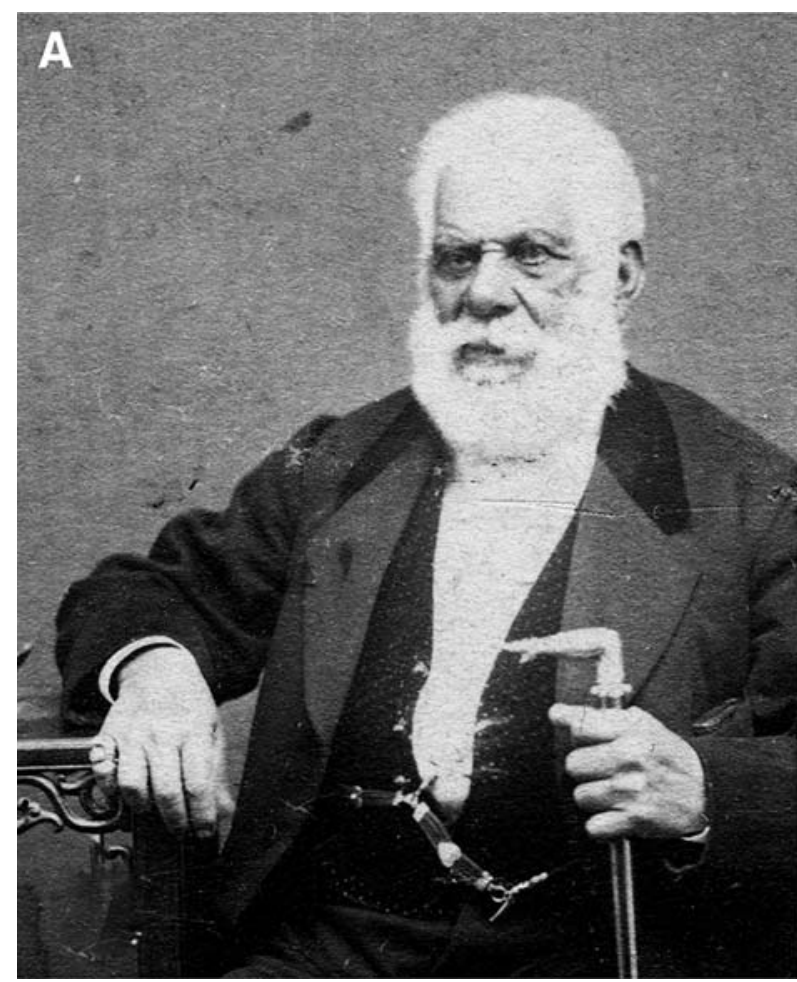

Fig. 5 (A) Pio Pico at about 89 years old c. 1890. This image is important because no obvious acromegalic features remain. His face and hands have a normal appearance (compare hands with Fig. 1). He now has lateral eyebrows and a full beard, supporting healthy pituitary physiology. Courtesy of the Anaheim Public Library. (B) This undated image reveals a rather distinguished, healthy appearing

in 1852, described Pio as, '...corrupt, non-English speaking, negroid, dwarfist and Latino...' " [27, p. 188]. Unfortunately, his grossly acromegalic physical features may have contributed to that prejudice. He was described as "having a face like a moose" [14]; or, at age 43, “...being repugnant in appearance..." [2, p. 266]. Perhaps the most scathing and public repudiation was by Gertrude FH Atherton (1857-1948), a highly acclaimed San Francisco writer. In 1902 she described him thus, “....an uglier man than Pio Pico rarely had entered this world. The upper lip of his enormous mouth dipped at the middle; the broad thick under lip hung down with its own weight. The nose was big and coarse, although there was a certain spirited suggestion in the cavernous nostrils..." [28]. It is unclear if she knew him personally.

Details of his political, social and business history abound $[2,3,6,7,11]$. Pio Pico was a powerful and influential force for almost a century as California passed from Spanish to Mexican to American rule. He manifested acromegaly during his time as a revolutionary politician spearheading secularization of Spanish missions, and he was likely acromegalic during his second California governorship, February 1845 to August 1846, when Mexico

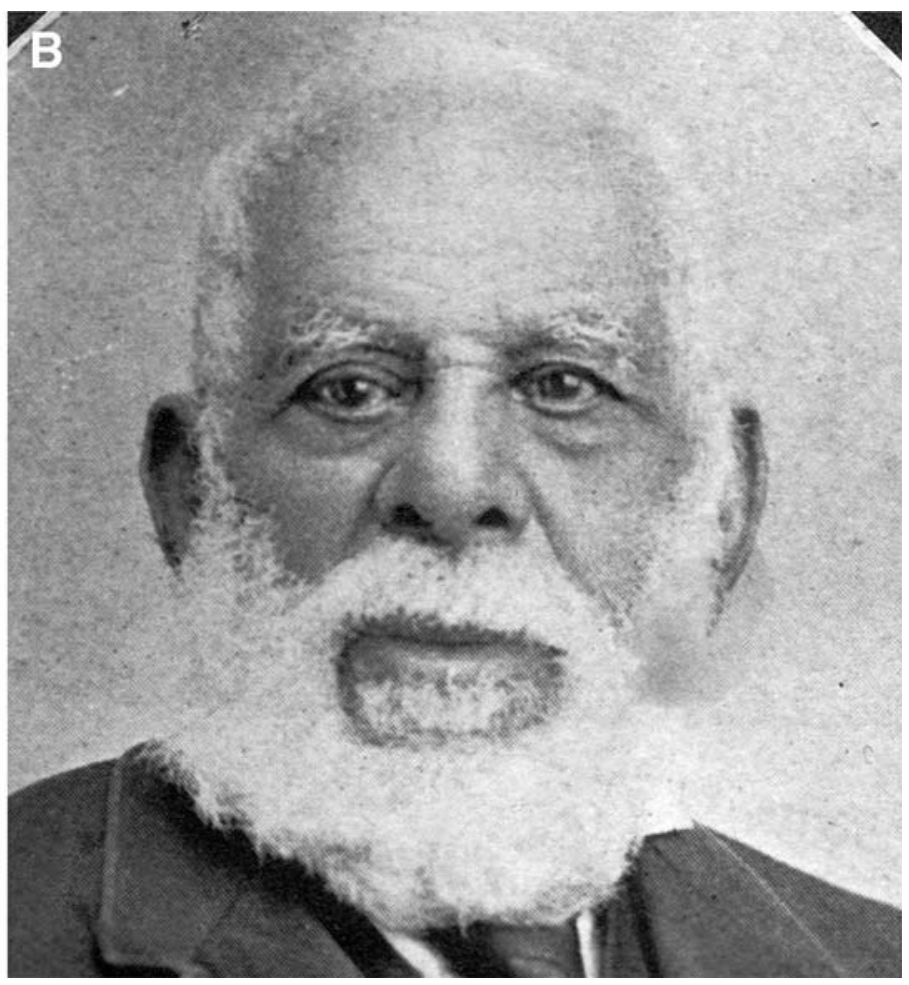

Pio Pico at an advanced age. The clear full-face comparison to Fig. 4 demonstrates resolution of acromegaly, return of conjugate ocular gaze without proptosis (note the symmetrical position of the light reflection in both eyes), healthy eyebrows, and generous facial hair. Courtesy of the San Diego Historical Society

surrendered California. Although most accounts abandon Pio at this point in his life, he prevailed dynamically under American rule, becoming one of the wealthiest California cattleman controlling more than a quarter million acres. He aggressively amassed his fortune and defended his position with over 100 legal cases including 20 argued before the California Supreme Court. Highly paid lawyers represented him as an honorable man and, "helped shed any negativity associated with his image" [3, p. 192]. Several poor business decisions and flagrantly fraudulent legal proceedings returned him to the utter poverty that began his life. His domineering presence led Pio to be considered, "one of the most clearly defined bridges that linked together Mexican and Anglo California" [3, p. 14]. Had prejudice been less pervasive, he and his contributions may have been more widely recognized in American history.

This unfortunate man suffered the dual hardship of an unrecognized medical disease and prejudice over his unavoidable appearance. The Pico family tree is exuberant [29]. Further research in personal archives and letters to identify the extent of his acromegalic symptoms should be exciting [1]. Might there be evidence of headache; clumsiness related to bitemporal visual field loss; sleepiness 
from obstructive sleep apnea; the need for a "mounting block" to mount his horse from proximal muscle weakness; joint pain; or excessive thirst and frequent urination from either diabetes mellitus or diabetes insipidus? We hope others will add depth to this rich story.

Acknowledgments The authors thank Marsha Lynn Login for her unfailing support throughout all facets of this project. Historians, research archivists and librarians in California and in England and respected colleagues at the University of Virginia provided critical insight and guidance to help accomplish our goal.

Open Access This article is distributed under the terms of the Creative Commons Attribution Noncommercial License which permits any noncommercial use, distribution, and reproduction in any medium, provided the original author(s) and source are credited.

\section{References}

1. Melmed S (2006) Medical progress: acromegaly. N Engl J Med 355:2558-2573. doi:10.1056/NEJMra062453

2. Dakin SB (1949) The Lives of William Hartnell. Stanford University Press, Stanford, CA

3. Salomon C. California son: the life of Pio Pico. Retrieved from Dissertations and Thesis database (AAT 3058948) 2002; 63-07 A: $1-244$

4. Wolff K, Johnson RA, Suurmond D (2007). Hypothyroidism and myxedema. http://www.accessmedicine.com/content.aspx?aID= 752831. Accessed $27 \mathrm{Feb} 2007$

5. Jane JA Jr, Thapar K, Laws ER Jr (2001) Acromegaly: historical perspectives and current therapy. J Neurooncol 54:129-137. doi: 10.1023/A:1012949214960

6. Gray PB (1998) Forster vs. Pico: the struggle for the Rancho Santa Margarita. Arthur H. Clark Co, Spokane, WA

7. Pico P (1973) Narracion Historica, Don Pio Pico's historical narrative. Arthur H Clark Co, Glendale, California

8. Bancroft HH (1963) History of California. W. Hebberd, Santa Barbara

9. Guthrie CL (1936) Hacienda of Governor Pio Pico. California Historical Landmark Series, Berkeley, California

10. Everett K (2007). The Avila heirs. http://www.sfgenealogy.com/ spanish/obitsa.htm. Accessed 13 Nov 2007

11. Cole M (1978) Pio Pico miscellany. Governor Pico Mansion Society, Whittier, California
12. Vils U. Pio Pico lives on in California folklore. LA Times 1983:11

13. Pio Pico Mansion (2007). http://www.laokay.com/halac/ PioPicoMansion.htm. Accessed 22 Feb 2007

14. Morris L (2007). Pio Pico remembered. http://www.sfvhs.com/ piopico.htm. Accessed, 22 Aug 2007

15. Portrait of Don Pio Pico and his wife. http://digarc.usc.edu/ search/controller/view/chs-m19400.html. Accessed 27 Feb 2007

16. Marie P (1886) Sur deux cas d'acromegalie: hypertrophie singuliere non congenitale des extremites supereures, inferieures et cephalique. Rev Med (Paris) 6:297-333

17. Sheaves R (1999) A history of acromegaly. Pituitary 2:7-28. doi: 10.1023/A:1009913719680

18. Marie P, Souza-Leite JD (1891) Essays on acromegaly. New Sydenham Society, London

19. Pearce JM (2006) Nicolas Saucerotte: acromegaly before Pierre Marie. J Hist Neurosci 15:269-275. doi:10.1080/ 09647040500471764

20. Brunori A, Bruni P, Delitala A, Chiappetta F (1995) Acromegaly and pituitary tumors: early anatomoclinical observations. Surg Neurol 44:83-87. doi:10.1016/0090-3019(95) 00008-9

21. Guillemin R (2006) Acromegaly, day one and now, 120 years later. Neuroendocrinology 83:136-138. doi:10.1159/000095520

22. Barnum Museum archive. http://lostmuseum.cuny.edu/archives/ guide3.htm. Accessed 20 Aug 2007

23. The Bancroft Library. University of California, Berkeley. Ex-gov. Pio Pico presented by himself. John A. Winberg, photographer [online]. Available at: http://content.cdlib.org/ark:/ 13030/tf6n39p2df/?\&quiry $=$ pio\%20pico\&brand. Accessed 22 Feb 2007

24. Verrees M, Arafah BM, Selman WR (2004) Pituitary tumor apoplexy: characteristics, treatment, and outcomes. Neurosurg Focus 16:E6-E13. doi:10.3171/foc.2004.16.4.7

25. Melmed S, Kleinberg D (2003) Chapter 8-anterior pituitary. In: Williams (ed) Textbook of Endocrinology, 10th ed. Philadelphia, Pennsylvania: Saunders, An Imprint of Elsevier

26. Bailey P (1898) Pathological report of a case of acromegaly, with especial reference to the lesions in the hypophysis cerebri and in the thyroid gland: and a case of hemorrhage into the pituitary. Philadelphia Med J 1:789-792

27. Fox J (2000) Macnamara's Irish colony and the United States taking of California in 1846. McFarland and Company, Inc., North Carolina

28. Atherton GFA. The Pearls of Loreto. In: The Splendid Idle Forties. Kentfield, California: Allen Press, 1960, 26

29. de Valdes y Cocom M. The blurred racial lines of famous families. http://www.pbs.org/wgbh/pages/frontline/shows/secret/ famous/pico.html. Accessed 19 Nov 2007 